\title{
21
}

\section{Subject/Object Relations and Consumer Culture}

\section{Shona Bettany}

It is possible to argue that all work on consumer culture deals explicitly or (more often) implicitly with subject/object relations. This chapter therefore moves between the implicit and explicit to render an understanding of the vista of theoretical underpinnings around subject/object relations and consumer culture. The chapter begins with studies of consumer culture and qualitative and interpretive culturally-oriented consumer research and examines their implicit underpinnings, and the political/ideological assumptions of the nature of subject/object relations that endures even in work that purports to challenge these assumptions, using three exemplar texts to illustrate the arguments made. The chapter then moves outwards into the broader disciplines that concern themselves with consumer culture, to examine the theories of subject/object relations that allow the reader to locate and situate this within its broader intellectual milieu. I conclude with three theoretical areas that directly relate to the subject/object relation that provide fruitful, challenging and insightful theoretical bases with which to deliver research and thought on consumer culture and materiality for the future.

Examining subject/object relations in cultural theory raises two inextricably linked issues. Firstly, in terms of the character of the relation between subject and object, as Hoskins (2006) argues, since Mauss (1924) and Malinowski (1922) cultural theorists have asserted that the lines between persons and things are culturally variable. Secondly, in terms of the hierarchy of the relation between subject and object, as Arnold et al. (2008) assert 'in its valorisation of the world of the mind, Western thought has long defined itself as above the world of things' (Arnold, Shepherd and Gibbs, 2008: 48). That is, different cultures not only assign, or perform, 
the descriptors 'subject' and 'object' differently, and draw the cultural boundaries between those nomenclatures differently, but, in Western cultural thought at least, they privilege that which is designated subject over that which is designated object. So what?, you might ask. Well, I suppose it depends whether one is designated a subject or an object! How does that happen, though? Taken from the dominant neo-liberal humanist perspective of Western thought, it could be argued in a common-sense way that objects are usually inanimate things and subjects are usually human, so taken from this perspective although 'we' think we know instinctively what is a subject and what is an object, it can still be argued that some things can become more subject-like (for example a prized sports car, an AI gadget, a talisman, a sentimentally valued heirloom, etc.) and some human subjects can become more object-like (for example, a slave or trafficked person, a refugee as seen through the lens of the right-wing media, even a much photographed and desired model or celebrity). Sticking with common sense, we seem to have no problem in developed and rational Western society in imbuing inanimate things with human subject-like qualities, with power, with thought, even with feelings, and, sadly, the corollary to this is that we have no problems, it seems, in objectifying certain other humans, giving them less than subject status, for a variety of functions and purposes. The central construct around which such designations are performed and become obdurate, lasting and eventually common-sense is agency. Subjects have agency, that is, they can 'act', objects, from this common-sense Western perspective, are acted upon, and, importantly within this worldview, any subject-like qualities are those that particular human subjects 'act upon' objects, and the meaning of those qualities resides in the minds and meaning systems of the human subjects that possess, experience, know or desire them. Any reader with little or no understanding of the theoretical vista around subject/object relations would read the above and recognise it as a part of the Western cultural understanding that allows us to categorise the sides and shades of this important structural binary.

The Western cultural common-sense understanding of subject/object relations outlined above, is where I start in this chapter, to outline the vista of understanding of subject/object relations in cultural theory relating to consumption. Cultural consumer studies are replete, 
unremarkably, with considerations of subject/object relations. The dominant underpinning assumption of the subject/object relations, I would argue, is that consumer subjects buy material objects to consume, reject, pay to experience them, or desire them, and it is this relation and all its baggage that continue to dominate the theorising around consumer culture. The consumer subject has agency, and can buy, act on and dispose of a range of non-agentic objects, and this relation and its myriad activities, meanings and experiences provides contextual fodder for the studies of, and underpins the theorising of, consumer culture. It is this set of Western commonsense underpinning assumptions about the subject/object relation, or binary, that this chapter explores, outlines and unpicks in order to deliver a deeper understanding to the reader of the role the subject/object binary plays in consumer culture studies, and what part it might play in the future.

Where I entered the debate about subject/object relations and consumer culture began with an intervention into interpretive, and culturally oriented consumer research with a critique of the handling of subject/object relationships within that paradigm (Bettany, 2007). Having recently completed an interdisciplinary $\mathrm{PhD}$ between sociology, feminist science studies and marketing (Bettany, 2005) I was immersed in the world of feminist material-semiotics (Haraway, 1992), actor-network theory (Latour, 1987; Law, 1992), heterogeneous networks (Callon, 1986) and agentic objects (Latour, 1992), and was dismayed to see the discipline of consumer research behind the meta disciplinary curve on the theorising of subject/object relations. The humanist, interpretive roots of the counter positivist movement (Belk, 1988; Hirschman, 1986) dominated a consumer-centric understanding of the subject/object relation (here mainly wrought as the relation between consumers and things); the object fulfils a myriad of functions for the consumer, but the underpinning philosophy of the relation remained as outlined in the Western neoliberal common-sense approach outlined above, that consumers are agentic, and use objects for a range of identity projects, experiences and meanings. This is outlined in the example used to explain the differences between humanism and positivism given by Hirschman in her 1986 paper, as follows; 
A positivist researcher investigating a consumer sub-culture might envisage the task as one of identifying exogenous background variables (e.g., socioeconomic status, geographic locale, and recency of immigration), which might influence group members' relative social mobility, achievement motivation, and materialism, which in tum may contribute to the group's preferences for certain types of apparel, home furnishings, and leisure activities. Thus a three-stage a priori model would be conceived and the researcher would try to operationalize and measure the several causes and effects composing the model. A humanist researcher investigating the same consumer subculture would work very differently. Because the goal is to understand the phenomenon in its own terms, the humanistic researcher would view the subculture as an amalgam of its members' values, actions, beliefs, motives, traditions, possessions, and aspirations. The researcher is primarily interested in learning the group's construction of reality and, for a marketing research study, how possessions, purchasing, apparel, automobiles, and leisure time activities fit into that reality. (Hirchman, 1986: 240-1)

In this comparative example, it can be seen that humanistic enquiry, like positivistic enquiry, albeit in a very different manner, privileges the human subject, and makes the assumption that the subject of enquiry is the subcultural group's members. How objects are dealt with in this type of analysis is only in terms of how consumption objects fit into those subjects' socially constructed realities. These humanist underpinnings have two main consequences. Firstly, following this history of thought within consumer research, the object in interpretive and culturally-oriented consumer research remains largely essentialised as something which is acted on, a 'thing in itself' that 'groups use' to construct 'practices, identities and meanings - to make collective sense of their environments and to orient their members' experiences and lives' (Arnould and Thompson, 2005: 869). Secondly, this then provides a theoretical rendering of the part the consumption object plays in consumer culture, which is incommensurate with contemporary theories of cultural materiality where theories have been developed which 
challenge the Cartesian subject/object binary and 'examine the entangled co-production and ontological indeterminacy of subject and object in cultural processes and action' (Bettany, 2007: 42).

The primary researcher explicitly examining subject/object relations within consumer culture, within this historical period in consumer research, and one of the pioneers of the movement away from the dominant positivist paradigm in the consumer research discipline, Russell Belk (1988), developed the theory of the extended self, a thesis that through its examination of possessions and self, developed a theory of subject/object relations in consumer culture that has become one of the most influential and important works in the discipline. Belk's original thesis is that we as humans develop and maintain our sense of self partly through the possessions we own. Belk uses as evidence for this, the harm to sense of self when possessions are lost or stolen, involuntarily dispossessed; the trends of materialism and self-definition in contemporary Western society being more about what one owns than what one does, and selfinvestment in possessions. Belk outlines special categories of possession that are most commonly incorporated by the human subject into the sense of self, 'collections, money, pets, other people and body parts' (Belk, 1988: 140). The implications of this incorporation of possessions into the self of the consumer are seen here predominantly in terms of defining meaning in life. Given that this watershed paper explicitly focuses on consumer subject/object relations, and was groundbreaking at the time in relation to this issue, the interpretation of the influence of that paper since then (Arnould and Thompson, 2005; explained further by Arnould, 2014, as documented in Ladik et al., 2015) is in its contribution to the development of theorising consumer identity projects. In other words, the agential primacy in the subject/object relationship theorising emerging from this hugely influential paper going forward is given most resolutely to the human consuming subject. Given this, it is perhaps unsurprising that it took until nearly thirty years later for papers to emerge that explicitly flipped this agency in order to challenge the common-sense understanding of subject/object relations in consumer culture theory. Given that this was the paradigm-shaping theory in consumer culture studies at the time 
I was doing my doctorate, in order to discuss a range of subject/object cultural theories I shifted my attention towards feminism, sociology, and science, technology and society studies.

More recently (Bettany, 2016) I revisited the critique in my original work, ten years on, and found that despite the plethora of work drawing on the disciplines and writers spearheading this focus on subject/object relations, the underpinning common-sense Western humanist, neoliberal philosophy of subject/object relations outlined at the beginning of this chapter largely persists in consumer research. As Campbell and McHugh (2016: 101), in the same volume, argue, consumer research is embedded in 'a correlationist view of human beings doing things in the world to inanimate objects to make immaterial effects happen. Where marketing scholarship has taken up the case of materiality interest has lain not in stuff but in our human relation to it'. The result, they posit is that studies of consumption have remained stubbornly about 'humans interacting with humans'. Two key works that have emerged in the interim that explicitly challenge this hegemony of subject/object common-sense relationality are outlined below, and can be used to explore a challenging paradigm to that outlined in the opening sections of this chapter. The first is my follow-up paper from the original critique chapter (Bettany, 2007), 'Figuring companion-species consumption' (Bettany and Daly, 2008). In this article I use actor-network theory and feminist material-semiotics to analyse how pedigree dogs, due to being simultaneously performed as within the categories subject and object, nature and culture, and oscillating between these binaries in complex relationships with a range of heterogeneous actors, co-enable simultaneously conflicting cultures of subjectification and objectification, nature-ing and culture-ing, in international dog exhibition and breeding cultures. Drawing on Haraway's binary collapsing naturecultures trope I develop the idea of naturecultural consumption to explain how dog feeding and grooming practices emerge and are shaped by a drive to make sense of and reconcile the boundary-defying ontology of dogs. The second exemplar text I draw on Epp and Price (2010), whose work draws on Kopytoff's (1986) theory of the cultural biography of things and Daniel Miller's (1987) (see below) work on material culture to explore and theorise the agency of a dining room table in the lives of an extended family. In doing so they use the concept of singularity, where objects are given 
personal meaning, to explore how singularised objects move in and out of networks, effectively becoming decommodified and recommodified, how the singularised object agency is constrained and enabled by the network within which it is embedded , and ask how the network is affected similarly by the singularised object.

Both Epp and Price (2010) and Bettany and Daly (2008) clearly articulate their theoretical positions as moving on from the consumer identity-work focus of interpretive and culturally-oriented research on subject/object relations which have dominated the subject/object theoretical vista since Belk (1988), as outlined above. Both of these papers are ontologically different from the mainstream in terms of their approach to subject/object relations in consumer culture along three main lines, what is agency? What is/becomes an object/subject? and what is a relation? Although both papers draw on different theories of materiality, the understanding of these questions is very similar, and highly counter-intuitive to the dominant conceptualisations more commonly found in consumer research.

Taking the first of these theories, actor-network theory (ANT) (see Cochoy and Mallard, this volume), which is drawn on in both papers, this school of thought emerged in the 1980s, just prior to the first of Belk's influential works on subject/object relations in consumer culture research. ANT emerged initially from the sociology of science and technology (SST) and science, technology and society (STS) and initially produced beginning studies of laboratories and scientific endeavour (Callon 1986; Latour 1987), and quickly extending to research examining socio-technological networks in a wide variety of contexts (Law, 1992; see also Bajde, 2013 for an excellent review). The primary driver of the emergence of ANT was the debates in SST and STS about the agency of technologies, and the dominant heroic stories of the production of science and technology. It can be argued therefore that the basis for the emergence of ANT was a critique of common-sense notions of subject/object relations that had become ossified in scientific and technological stories. The key central questions in SST/STS were around the relationship between people/society/science and technologies and the relationship of the scientist subject and his studied/discovered objects. The fields of STS and SST prior to this were dominated by a dualist argument (somewhat reified and simplified here 
due to space constraints) between social determinism and technological determinism (see MacKenzie and Wajcman (1999) and Latour (1992) for further reading on this). In social determinism the social (i.e. the human subjects) determined the shape of the technologies and discoveries that emerge, in other words, the needs, wants, desires and cultural mores of a society, and the human subjects involved directly in these areas, determine what science and technology produces and discovers. On the other hand, technological determinism arguments held that technologies and discoveries were not shaped or produced by human subjects like scientists, or by society, but emerge through the logic of heroic discovery, and in their turn shape society (and the activity of scientists and technologists) around them. It is likely that, as most readers would deduce, everyone understood that a more complex combination of the two is going on, and the texts, read in depth, reflect that, but at the time in the early 1980 s there was not a theoretical hook to hang an alternative explanation on. ANT then emerged as a hugely successful and influential actor in its own right (see Law, 1999) to provide an alternative to the common-sense and essentialist subject/object dualism inherent in both of these accounts. To unpick that sentence, both accounts see an already pre-existing subject and object (an essentialist idea of what subject and object is - this is taken as common sense). The point of analysis in both is the relationship between the two (the relation between two already preexisting entities) and the point of difference between them is merely from which way round comes the shaping of technology and society (i.e. where is the majority of the agency coming from). ANT handled subject/object relations and agency in a very different way. As Latour explains:

Those advocating the actor network approach agree with the social constructivist claim that sociotechnical systems are developed through negotiations between people, institutions, and organizations. But they make the additional interesting argument that artefacts are part of these negotiations as well. (Latour, 1992: 151)

Latour (1992) was at pains to argue for analyses that attended to what he called 'the missing masses', that is, the artefacts and objects that have been long ignored by theorists of social and 
cultural life. The ontological basis of ANT is material-semiotic (meaning and materiality are entangled and inseparable in analysis), and the research is based on in-depth ethnographic studies of networks of heterogeneous human and non-human actors (Haraway, 1991; Law, 1999), with a flat, symmetrical ontology which implies that all human and non-human participants in an analysis should be treated as equal, active participants. Agency, therefore is a central construct changed from the dominant ideas of agency outlined in the previous sections. Agency, as seen in the Western (particularly individualist neoliberal) cultures, relates to the ability to do reflexive, purposeful, goal-directed activity and is almost exclusively attached to the primary sentient being, namely human subjects (although other non-human animals - like dogs - get somewhat of a look in too). Objects, in this view, are seen as not having agency, and human society becomes a little paranoid and worried when stories emerge around non-human, non-sentient agentic developments (see for example, Belk, 2016). However, Latour (and other ANT theorists) argue that agency should be reconceptualised as an outcome of networks of actors, rather than an impulse or drive of the individual subject. Latour (2000: 192) argues that 'purposeful action and intentionality may not be properties of objects, but they are also not properties of humans either. They are properties of collectives of human and non-humans'. Latour's argument is that agency is linked to how the meaning and materiality of objects, bodies and other entities emerge. Agency is not something that human actors have (and apply) to the material world around them. The material object (and the subject) emerge as effects of the surrounding relations within which they are embedded. That is, meaning and materiality, subject and object, co-emerge and are co-constituted. Meaning and materiality are embedded within complex socio-material assemblages of people, things and ideas (Canniford and Shankar, 2013; see also DeLanda, 2006 for further insights into the assemblage concept). 'ANT seeks to understand how these assemblages become stable or fail to achieve stability (Latour 2005)' (Bettany, Kerrane and Hogg, 2014: 7). This not only means a change in what is deemed to have agency in analyses, but also in what agency as a concept actually means. Furthermore, again challenging the subject/object common-sense articulation, in this worldview subjects and objects are not essential things, pre-existing the analysis of their relation, but are also effects of 
the heterogeneous network, not only in terms of what kind of subject or object they emerge as within the network (remember the idea above that we naïve readers can see as sensible - that objects can carry meanings that make them more subject like, and vice versa) but in terms of the network actually producing them as object or subject per se. In both of the example texts I have used, these challenging ideas to the mainstream paradigm understanding of subject/object relations are evident. In Price and Epp's work, the table has agency within the network and the analysis looks at the variable agencies produced by the network that change what might be seen as the essential nature of the table, it is commodified and decommodified, has a singularity that might vary depending on its locations within the network. In Bettany and Daly's work, the deliberate choice (following Haraway, 2003) of an ambiguous subject/object (the dog) is used to understand how the processes of subjectification and objectification within the network result in complex regimes of care, and ontological oscillation of the dog, the human subject, the culture of dog exhibition and a myriad of other human and non-human actors. As documented in Bettany (2016), other works drawing on these symmetrical, processual and emergent approaches to the subject/object relation in consumer research are: Bettany and Kerrane (2011), who use actor-network theory to examine how mass-produced plastic chicken coops are made and remade as important actors within the network of families in the context of the formation and maintenance of identification with a voluntary simplified lifestyle; Giesler (2012), who uses Callonian ANT theory (Callon, 1986) to theorise the market-making processes around doppelganger brand management using the example of Botox; Hui (2012), who examines mobile assemblages of people and bird-watching; Thomas, Price and Schau (2013), who use ANT, in their study of long-distance runners to examine how heterogeneous communities align their interests and achieve cohesion through resource-dependence; Bettany and Kerrane (2014), who use ANT to theorise how caring technologies co-configure ambivalently gendered actornetworks within new family settings; Hansson (2014), who uses ANT to elaborate on how objects on their journey from shop to home are co-constitutive of moving consumers in urban space; Martin and Schouten (2014), who use ANT to theorise how consumers mobilise human and non-human actors to co-constitute products, practices and infrastructures towards new 
market emergence in the motorcycle industry; Epp, Schau and Price (2014), who examine how brands and technologies mediate long-distance family relationships; and Parmentier and Fischer (2015), who conceptualise brands as assemblages of heterogeneous components and examine how fans contribute to the destabilisation of a brand's identity. Other writers have produced theoretical/conceptual papers outlining this alternative approach to subject/object relations. Examples here include: rethinking ontologies of consumption as enacted through precarious networks of heterogeneous relations (Bajde, 2013); discussing as taken for granted the concepts of materiality, materialism and agency and connecting consumer research to highlevel theorizations of materiality (Borgerson, 2014); outlining the differences between ANT and other consumer theories, taking into account non-human actors (Belk, 2014); illustrating how non-representational theory can augment existing ANT applications in consumer research (Hill, Canniford and Mol, 2014); and, finally, Canniford and Badje's (2016) excellent edited collection of work on the engagement of heterogeneous assemblages with consumer research studies.

Many of the above selection of works, it might be argued (and I include some of my own work in this critique), differ somewhat from the exemplar texts used to delineate in detail the theoretical debate on subject/object relations in consumer research. In them, the reader might find the ghost of humanism and the Western agentic subject (as exemplified in the 'objects as primarily identity formation tools' paradigm critiqued above) are very much present! I argue that this has occurred for two reasons. Firstly, as mentioned before, interpretive and culturally oriented works' roots in the humanistic, semiotic approach to consumer research (e.g. Hirschman, 1986) that was a necessary political response to mainstream positivism continues to make the emphasis on human meaning and action the dominating worldview. Secondly, and perhaps more contentiously, I would argue that due to its dominance by US journals (particularly JCR and JM) perhaps unreflexively mirrors the neoliberal political ideology that reflects the political conditions (i.e. the USA) from which it emerges. The neoliberal political worldview sees the human (consumer) subject as free, choosing, and with primary agential 
power. The neoliberal subject has an individualist purview, with responsibility for the self, and human outcomes are rendered through free, autonomous (consumer) choices made within a competitive market-based political economy (Ball et al., 2012). Taking this as the starting point for analysis of subject/object relations it then becomes highly problematic to reconfigure consumer agency as 'made up in the multiplicity of material-semiotic heterogeneous actor networks within which it emerges, much less that objects and non-human others should be dealt with symmetrically in analysis, or that human intentionality needs to be carefully written out of accounts'. In reading (particularly US published) accounts drawing on theoretical approaches that challenge the common-sense subject/object relation assumptions of neo-liberalism 'one can read the struggles between the lines ... consumers assemble experiences and collectives, managers struggle with brands and markets, consumers make markets using resources' (Bettany, 2016: 192). I recognise these struggles very well from my own encounters with reviewers! Although all of the works ostensibly draw on symmetrical and emergent ontologies in terms of subject/object relations, it might be a worthwhile exercise for the reader new to these debates to try to categorise the empirical works above into those where the Western humanist, agentic consumer subject still stalks the pages, and those where the ontological symmetry and emergent nature of subject and object is, as far as possible, theoretically expressed. Please note though in this exercise, the aim is not to critique the authors but to rather to critique the conditions of possibility of the discipline.

Having written a substantial amount outlining and then challenging the dominant idea about (human/consumer) subjects and the kind of agency implied in our Western understanding of them, using three exemplar texts (Belk, 1998; Bettany and Daly, 2008; Price and Epp, 2010) to draw boundaries between the dominant and challenging theoretical paradigms of subject/object relations in interpretive work within the discipline of consumer research, it is necessary now to dig down into the theoretical vista of objects, things and materiality to further develop the discussion on subject/object relations in consumer culture. The key concepts used to theorise subject/object relations in consumer culture studies have been materiality, objects and affordances. As described above, objects in interpretive qualitative work in consumer 
research have tended historically to be defined in terms of something that 'groups use' to construct 'practices, identities and meanings - to make collective sense of their environments and to orient their members' experiences and lives' (Arnould and Thompson, 2005: 869), with, as I have argued above, an enduring humanist flavour. However, the wider social sciences around cultural studies handle 'the object' very differently.

One of the primary theorists of materiality in relation to consumer culture is Daniel Miller $(1987,1988)$, who, in the relational ontology tradition, akin to Latourian work cited above, for example, seeks to challenge the subject/object dualism and understand how we consume with and through material objects. He is situated within material culture studies, an interdisciplinary space for research into the ways in which 'artefacts are implicated in the construction, maintenance and transformation of social identities ... the investigation of the relationship between people and things irrespective of time and space' (Miller and Tilley, 1996: 5). This relation is seen as an ongoing dialectic rather than dichotomy, as in subject creating object creating subject (Geismar, 2011). Miller's first book directly dealing with this area, Material Culture and Mass Consumption (1987), was the start of an ongoing large and prolific publishing career that is international and multi-audience in scope, and recently has fully embraced the new technological vista of society, for example Facebook and social media, in relation to consumption and life (Horst and Miller, 2013). The importance of Miller's work is outlined by Borgerson (2009), where she makes the point that Miller has highlighted the oft-ignored relation between 'consumption-based assumptions and theories of materiality' (Borgerson, 2009: 155) and argues that Miller's position vis-à-vis this relation, as outlined in this early book, drawing on a hybrid rendering of subject/object relations, is that 'consumption is a process by which human beings materialise or objectify values and meanings' and 'resolve conflicts and paradoxes in everyday life'. Objectification is an important concept in Miller's work, where, drawing on Hegel, he shows how value and meaning, for example, pass between people and things in a dialectical relation. Objectification refers to the activity by which human beings fashion themselves in the external world through consumption activities, by which he means 'the diverse appropriations by which consumers turn impersonal, standard commodities 
into personal, singular possessions. This activity of appropriation is "consumption work" (Foster, 2011: 44, see also Miller, 1987). Although Miller's work is kaleidoscopic, and one needs to read a range of his work to reflect and understand this, for the purposes of this chapter about subject/object relations and consumer culture, the book I would recommend to early readers on materiality and consumption would be Stuff (2010). The aim of Stuff is to provide an account of Daniel Miller's personal and research anthology over around thirty years of his ethnographic study of material culture. In terms of theoretical positioning, vis-à-vis the subject/object relation, Stuff characterizes much of Miller's work, as it is a pulling together of the different and diverse strands of his work, to give a broad picture of the range of work (and perspectives on material culture) by this author. Stuff illustrates Miller's more anthropological, dialogic rendering of the subject/object dualism to ANT, for example, which has tended in some treatments to focus more on the object in the analysis. I would characterize many ANT studies as shading into more of an object-oriented ontology (OOO) than Miller's work, but would also note that for me this flipping of (privileging of) the object in analyses is a necessary political move to counter the primacy of the human subject in analyses (see also Blackhurst, 2015; McHugh and Campbell, 2016). As might be expected from someone situated within anthropology, the context and descriptions in Miller's work are rich and his work is theoretically diverse. As Hart (2010) in his review of Stuff argues, Stuff typifies Miller's approach throughout his work that 'people not only make things, but things make people, that is, we are unconsciously shaped by the artefacts that surround us'. This illustrates that, in common with ANT, Miller does not begin his analyses with an essentialised notion of what the subject or object of his study is, in contrast to the Western common-sense notions of this as reflected in much of consumer studies, and outlined above, but sees what is the subject and the object as outcomes of relations. It is for this reason he forms an important part of what might be called the oppositional paradigm to the dominant views on subject/object relations, as recounted earlier.

A new entrant into the lexicon of consumer culture studies vis-à-vis subject/object relations is the concept of affordances. This is not a new concept in itself but one that has 
gradually started creeping into stories of assemblages, socio-techno networks and distributed agency, of the approaches outlined above when applied to consumer culture theorisations. As argued above, socio-material approaches derive from and are mainly utilised to analyse humantechnology relations. Technologies are seen as constructed in reciprocal socio-material relations, where it is assumed that technological objects have certain 'affordances' that suggest what potentials they offer in a relation with the user (Akrich and Latour, 1992; Bloomfield et al., 2010; Pfaffenberger, 1992). The idea of affordances, originally from ecological psychology (Gibson, 1979) was developed as a theory to help understand from an interactionist perspective how abilities and constraints in action are based on relational agent situation interactions. Put simply:

in any interaction involving an agent with some other system, conditions that enable that interaction include some properties of the agent along with some properties of the other system ... affordance refers to whatever it is about the environment that contributes to the kind of interaction that occurs. (Greeno, 1994: 338)

It is therefore a theory about object ('environment') agency as defined within a set of relations. Affordance theory migrated to studies of the socio-technical, and here it is argued that they 'are not reducible to their material constitution', that is they are not a list of features, 'but are inextricably bound up with specific, historically situated modes of engagement and ways of life' and that analysis should focus on 'how specific action possibilities emerge' (Bloomfield et al., 2010: 420). In other words, it is a means to understanding the possibilities of what can be done (possible agencies) as a result of the relation between subject and object, what activities and constraints the object/subject relation affords. As Gibson (1979/1986) argues, affordance cuts across the subject/object dichotomy, and he was at pains to dismiss the notion that meaning and opportunities for action of objects are products of the human or animal mind (Withagen et al., 2012). As a means to study the attribution of action possibilities in relation to technologies, affordance theory has been utilised in studies of how disability gets constituted alongside technological artefacts such as computers (Bloomfield et al., 2010); the affordances of play 
areas for children's physical development; the consumption of music in a digital age (Nowak, 2016); how poor youths and mobile phone usage objectified the digital divide in Sri Lanka (Wijetunga, 2014); how learners and mobile learning institutions are linked and produce technologies designated as 'for learning' (Wright and Parchoma, 2011); the moral affordances of alternative tourism, through the digital site couchsurfing.com (Molz, 2013); technologies of social media in organisations, with specific regard to the emergence of new organisational communications styles (Treem and Leonardi, 2012); and how new digital technologies and backpackers create new forms of tourism and mobile society (Molz and Paris, 2015). In consumer research, although, as mentioned above, the term affordance/s has started to be mentioned in specific research, it is very early days in terms of developing affordance theory. A search of the Journal of Consumer Research (04/01/17) found several very recent articles within this school that mention affordances but do not conceptualise or theorise the term (Williams-Bradford and Schouten, 2015; Dolbec and Fischer, 2015; Figueiredo and Scaraboto, 2016). As mentioned, although the term has crept into the lexicon, it has not been the articulated focus of the work, and has therefore, understandably, not being defined nor conceptualised. One recent paper (Bettany and Kerrane, 2016), within studies of consumer culture, that has addressed this hiatus has used a combination of affordance theory and neutralisation theory to examine the uptake and consumption of a controversial product, the child surveillance tracker. This is an electronic, GPS and often SIM-enabled device that parents buy to track the movement of their children. It has found that the positive and negative affordances rendered between parents, children and the product co-enact and cohere ambivalent parental styles of laissez-faire and over-controlling parenting in the accounts of parents using this technology. The importance of this for thinking about subject/object relations and consumer culture is to take a socialpsychological theory, oft used to understand and theorise controversial consumption and how consumers rationalise and justify their use and purchase of them, neutralisation theory - a theory that makes assumptions about the dominant perspective on subject/object relations - and engage it with a theory that assumes the challenging paradigm's perspective on object and subject relations, including the relational agency of the consumer subject and their consumption 
object. In doing this, new and fresh understandings of how consumers, together with the action possibilities and constraints of their consumption objects, collectively make sense of their consumption in terms of (in this case) parental style. Understanding the often conflicting agencies that emerge from this relation can, we argue, help designers, marketers and policy makers to gain new insights that cannot be found in studies of the human subject/social alone.

A final influence on the theories of subject/object relations I will discuss in cultural studies of culture, consumption and materiality, is feminist material-semiotics, as outlined and promulgated primarily by Donna Haraway. Coming from a feminist perspective, for Haraway, and many other feminist theorists, dualisms (like subject/object) and the way that these are assigned, performed and hierarchized have been a key and enduring political target. This is because in their hierarchies, they often reflect the binary masculine/feminine, so for example, women are culturally reduced to the body (object/nature), and men to the mind (subject/culture). This reflects the masculinist and patriarchal Cartesian underpinnings of much common-sense cultural understanding. Material-semiotics recognizes that the material world of things and the semiotic (how meaning is made) are co-constitutive and emergent, and as such akin to the subject/object hybridity of the alternative theories outlined above. In fact, John Law, one of the primary theorists associated with the emergence and success of ANT has argued that it is better to talk about material-semiotics than ANT, as the former 'catches the openness, uncertainty, revisability and diversity of the most interesting work' (Law, 2009: 142). Haraway, being primarily a feminist, has critiqued the ostensibly acritical nature of ANT and asked what difference do such studies make, and as such, using her binary-challenging material-semiotic tropes, like the cyborg and companion species, unpicks worlds that might be otherwise, through challenging taken-for-granted formulations of the way things are. The cyborg (cybernetic organism), her most influential trope, is used to destabilize the subject/object (and concomitantly the human/non-human) binaries to unpick the cultural assumptions about them written into scientific, political, popular and academic accounts and to the detriment of marginalized groups and inequalities. Her later work uses companion species (Haraway, 2003), 
notably, dogs, as a way to disrupt the subject/object binary. This use of a mundane (pet dog) rather than mythical, futuristic (cyborg) trope is deliberate, and illustrates the hybrid nature of the commonplace. I used this as a theoretical lens in my critique chapter and the example paper given above (Bettany, 2007; Bettany and Daly, 2008), deliberately looking at dog exhibition and breeding cultures, an often denigrated, not-taken-seriously context, to show how nationalities, histories, cultures and worlds are built from the assumptions around these mundane but taken from granted subject/object and nature/culture binaries, and what consumer culture theory can learn from this. Haraway's subject/object hybridity stems from her feminist politics, and can be understood as an intervention in the dominant ideas of purity and the 'truth' of essential binary structures around culture and the systems of knowing of it. Here she draws on the work of anthropologist Mary Douglas (1966) about how the body is 'made up' culturally, and not an essential taken-for-granted, where hybridity and impurity are seen as taboo and liminal, and she uses deliberate tropes of impurity (like the Cyborg) to expose and challenge the binary certainties underpinning much inequality. This positions her work differently to all of the above, although she allies herself with both cultural studies and science studies, within which all are located, what distinguishes her work is that her quest is to produce knowledge of the world that can disrupt structured inequalities and knowledge regimes and unquestioned realities, particularly scientific objectivism, that keep these structured inequalities obdurately commonplace and natural, 'knowledge-power processes that inscribe and materialize the world in some forms rather than others' (Haraway, 1997: 7). To explain further, if subjects and objects are being 'made up' in relations, then there can be the assumption that different orderings or types of those relations can make up different subjects and objects, with different outcomes for the world. What Haraway calls 'the relentless commitment to show the established disorder is not necessary, nor perhaps even real. The world can be otherwise' (Haraway, 1994: 64). Newcomers to Haraway's work on subject/object relations (and other structuring binaries) might begin with the book Modest Witness (Haraway, 1997), particularly the way she presents material entities, the foetus, chip, seed, bomb, etc. and unpicks their imploded worlds of 
meaning and materiality, agency and agencies and her use of them in 'tearing down the Berlin wall between the world of subjects and the world of objects' (Haraway, 1997: 270).

In terms of future developments for subject/object theorising vis-à-vis consumer culture research, I see great possibilities in particularly affordance theory. This, firstly, is because I think that the concept of affordances allows a softer way in to relational agency for the USdominated neoliberal sub-discipline of consumer culture theory. The action possibilities idea enables a common-sense (although not strictly ontologically correct) understanding of human choice, that sits more easily with the aforementioned neoliberal political underpinnings. It is for this reason that, I would argue, it has started to emerge within the consumer culture theory lexicon. Secondly, In terms of the broader study of consumer culture I think it also has the promise to engage with and intervene in many sociological and psychological theories of consumer relations with material objects, beyond its current focus on technologies. In the example paper given above, I think that I have shown it can provide an alternative lens to understanding consumer cultures. On the other ontological extreme from humanism lies another future possibility for scholars interested in alternative paradigms of subject/object relations, object-oriented ontology (OOO) (see Campbell and McHugh, 2016 for a review). This approach is not, as far as I know, currently explored in studies of consumer culture, and thus it does not form part of my substantive review. However, OOO, rendered through Lingis (1998) asserts that our worlds are filled with non-human imperatives, to which we respond as objects. Further, and reminiscent of Haraway's imploded nodes of bomb, chip, foetus, gene, within OOO the concept of the hyperobject (Morton, 2013), an object massively distributed in space and time, also provides a fruitful and alternative ontological basis to explore the subject/object relation. It is somewhat of a misnomer to use this here, as OOO views everything as an object, and object-object relations are a focus. Bradshaw and Canniford (2010) (also see Canniford and Bradshaw, 2016) allude to the concept of hyperobjects in terms of how excrement is ubiquitous and thus resistant to disposition, a key concept in consumer research; hyperobjects like bacteria, ozone (or poo) cannot be 'put away' (Campbell and McHugh, 2016: 96) or disposed of. This directs the consumer culture researcher to the object as the centre of analysis in what might be 
described as a radical anti-humanist stance. The final area recommended for development in studies of consumer culture vis-à-vis the subject/object relation is feminist material semiotics. The reason for this selection returns me to my original critical work (Bettany, 2007) and, more particularly, my revisiting of this critique in Bettany (2016). Studies of consumer culture and materiality remain stubbornly acritical, and the interrogation of the rendering of the subject/object relation lies, I suggest, at the heart of a possible revitalized critique. As outlined above, Haraway's material-semiotics exposes the making up and hardening of categories, through binary opposition, where we take for granted 'what fits where'. In one example, in terms of ascription to subject and object, the turn to more language, or semiotically driven understandings of consumer culture, in the face of a new digital world concepts such as dematerialisation, immateriality and liquid consumption (as discussed in Belk, 2013; Bardhi and Eckhardt, 2012; Bardhi et al., 2012) have emerged. Material-semiotics can be employed within this conceptual universe to unpick and challenge the processes of the subjectification and objectification of human and non-human actors. So, for example, the serially interchangeable, dislocated (i.e. usually migrant), unconnected (i.e. not employed) worker, becomes as much an object within this world as his car, or the smart phone used to summon him by the privileged subject consumer. In this raced, classed (and often gendered) system of liquidised (I chose that word carefully, for this is a violence) bodies, and hyper-subjectified (i.e. with enhanced agency) consumers, a challenger theory that explicitly examines the making and ossification through consumer culture, and its theories, of the subject/object binary and its politics, is invaluable.

In conclusion, in this chapter I have attempted to outline the region of discourse around the subject/object relation in consumer culture studies. Firstly, to introduce the reader to this complex field I outlined a common-sense understanding of this relation, the terms of the debate - subject, object and agency - and gave some illustrative examples to explore what many readers might recognize as a commonplace understanding, but one which is quite specific to predominantly Western, neoliberal cultures; that is, that the subject is largely seen as hierarchically superior, with agency, and human, and the object is seen as secondary to, non- 
agentic, often non-sentient, and non-human. I then outlined my own engagement with the debates around subject/object relations, specifically, my interventions into the field of consumer culture theory, a sub-discipline of consumer behaviour research with a humanistic history that has coloured, and arguably continues the colour, the theorization around this important structural binary. I then presented three example texts to illustrate the dominant paradigm around subject/object relations in consumer culture theory, and its paradigmatic alternatives. Having done this, I outlined some of the major approaches and theorists that have been drawn upon from the broader social/scientific disciplines to formulate these alternative and successor approaches to subject/object relations. These approaches, although not a definitive list, outline broadly the background ontologies and politics of alternative approaches to guide the reader into a fuller understanding of the differences and similarities of the approaches on offer. These approaches are the ANT school, the work on material culture by Daniel Miller, affordances theory, and feminist material-semiotics. The reason for the choices made, are to offer the reader a cross-section of alternatives to the dominant humanist paradigm, not just in terms of differences ontologically, that is, the differences between how the humanist and ANT approaches see subject and object, but also politically, that is, how all the other approaches differ from feminist material-semiotics in that the politics of the subject/object relation are implicated in the structuring not only of inequalities, but that material-semiotic analyses can be used to expose fragility in seemingly taken for granted and obdurate power structures and suggest interventions towards possible different realities.

\section{References}

Akrich, M. and Latour, B. (1992) 'A summary of a convenient vocabulary for the semiotics of human and nonhuman assemblies'. In W.E. Bijker and J. Law (eds), Shaping Technology/Building Society: Studies in Sociotechnical Change (pp. 259-264). Cambridge, MA: The MIT Press. 
Arnold, M., Shepherd, C. and Gibbs, M. (2008) 'Remembering things', The Information Society, 24(1): 47-53.

Arnould, E.J. and Thompson, C.J. (2005) 'Consumer culture theory (CCT): Twenty years of research', Journal of Consumer Research, 31(4): 868-882.

Bajde, D. (2013) 'Consumer culture theory (re)visits actor-network theory: Flattening consumption studies', Marketing Theory, 13(2): 227-242.

Ball, S.J. (2012) 'Performativity, commodification and commitment: An I-spy guide to the neoliberal university', British Journal of Educational Studies, 60(1): 17-28.

Bardhi, F. and Eckhardt, G.M. (2012) 'Access-based consumption: The case of car sharing', Journal of Consumer Research, 39(4): 881-898.

Bardhi, F. Eckhardt, G.M. and Arnould E.J. (2012) 'Liquid Relationship to Possessions', Journal of Consumer Research, 39(3): 510-529.

Belk, R.W. (1988) 'Possessions and the extended self', Journal of Consumer Research, 15(2): $139-168$.

Belk, R.W. (2013) 'Extended self in a digital world', Journal of Consumer Research, 40(3): $477-500$.

Belk, R.W. (2014) 'You are what you can access: Sharing and collaborative consumption online', Journal of Business Research, 67(8): 1595-1600.

Belk, R. W. (2016) 'Extended self in a digital world', Current Opinion in Psychology, 10: 5054.

Bettany, S.M. (2005) The Making of Marketing Knowledge (Doctoral dissertation, University of Lancaster). 
Bettany, S.M. (2007) 'The material semiotics of consumption or where (and what) are the objects in consumer culture theory?', Consumer Culture Theory (Research in Consumer Behavior), 11: 41-56

Bettany, S. (2016) 'Where (and what) is the critical in consumer-oriented actor-network theory?' In R. Canniford and D Bajde (eds), Assembling Consumption: Researching Actors, Networks and Markets (pp. 187-197). London: Routledge.

Bettany, S.M. and Daly, R. (2008) 'Figuring companion-species consumption: A multi-site ethnography of the post-canine Afghan hound', Journal of Business Research, 61(5): 408-418.

Bettany, S. and Kerrane, B. (2011) 'The (post-human) consumer, the (post-avian) chicken and the (post-object) Eglu: Towards a material-semiotics of anti-consumption', European Journal of Marketing, 45(11/12): 1746-1756.

Bettany, S. and Kerrane, B. (2016) 'The socio-materiality of parental style: Negotiating the multiple affordances of parenting and child welfare within the new child surveillance technology market', European Journal of Marketing, 50(11): 2041-2066

Bettany, S.M., Kerrane, B. and Hogg, M.K. (2014) 'The material-semiotics of fatherhood: The co-emergence of technology and contemporary fatherhood', Journal of Business Research, 67(7): 1544-1551.

Blackhurst, A. (2015) 'From life writing to thing writing: François Bon's Autobiographie des objets', French Cultural Studies, 26(4): 426-438.

Bloomfield, B.P., Latham, Y. and Vurdubakis, T. (2010) 'Bodies, technologies and action possibilities: When is an affordance?' Sociology, 44(3): 415-433.

Borgerson, J.L. (2009) 'Materiality and the comfort of things: Drinks, dining and discussion with Daniel Miller', Consumption, Markets and Culture, 12(2): 155-170. 
Borgerson, J.L. (2014) 'The flickering consumer: New materialities and consumer research'. In R.W. Belk, L. Price and L. Peñaloza (eds), Consumer Culture Theory (Research in Consumer Behavior, Volume 15). Emerald Group Publishing Limited.

Bradshaw, A. and Canniford, R. (2010) 'Excremental theory development', Journal of Consumer Behaviour, 9(2): 102-112.

Callon, M. (1986) 'The sociology of an actor-network: The case of the electric vehicle'. In M. Callon, J. Law and A. Rip (eds), Mapping the Dynamics of Science and Technology. Houndmills, UK: Palgrave Macmillan

Campbell, N. and McHugh, G. (2016) 'OOO:Oooh!', In R. Canniford and D. Bajde (eds), Assembling Consumption: Researching Actors, Networks and Markets. London: Sage.

Canniford, R. and Bajde, D. (2016) Assembling Consumption: Researching Actors, Networks and Markets. London: Routledge.

Canniford, R. and Bradshaw, A. (2016) 'Shit happens', The Practice of the Meal: Food, Families and the Market Place, 10: 233-244

Canniford, R. and Shankar, A. (2013) 'Purifying practices: How consumers assemble romantic experiences of nature', Journal of Consumer Research, 39(5): 1051-1069.

DeLanda, M. (2006) A New Philosophy of Society: Assemblage Theory and Social Complexity. Edinburgh: A\&C Black.

Dolbec, P.Y. and Fischer, E. (2015) 'Refashioning a field? Connected consumers and institutional dynamics in markets', Journal of Consumer Research, 41(6): 1447-1468.

Douglas, M. (1966). Purity and Danger. London: Routledge and Kegan Paul.

Epp, A.M. and Price, L.L. (2010) 'The storied life of singularized objects: Forces of agency and network transformation', Journal of Consumer Research, 36(5): 820-837. 
Figueiredo, B. and Scaraboto, D. (2016) 'The Systemic Creation of Value Through Circulation in Collaborative Consumer Networks', Journal of Consumer Research, 43(4): 509-533.

Foster, R.J. (2011) 'The uses of use value: Marketing, value creation, and the exigencies of consumption work'. In D. Zwick and J. Cayla (eds), Inside Marketing: Practices, Ideologies, Devices (pp. 42-57). Oxford: Oxford University Press.

Gibson, J.J. (1979/1986) The Ecological Approach to Visual Perception. Boston, MA: Houghton Mifflin.

Geismar, H. (2011) “"Material culture studies” and other ways to theorize objects: A primer to a regional debate', Comparative Studies in Society and History, 53(01): 210-218.

Giesler, M. (2012) 'How doppelgänger brand images influence the market creation process: Longitudinal insights from the rise of Botox cosmetic', Journal of Marketing, 76(6): 55-68.

Greeno, J.G. (1994) ‘Gibson’s affordances’, Psychological Review, 101(2): 336-342.

Hansson, N. (2015) “"Mobility-things” and consumption: Conceptualizing differently mobile families on the move with recent purchases in urban space', Consumption Markets \& Culture, 18(1): 72-91.

Haraway, D.J. (1988) 'Situated knowledges: The science question in feminism and the privilege of partial perspective', Feminist Studies, 14(3): 575-599.

Haraway, D.J. (1991) Simians, Cyborgs, and Women: The Reinvention of Women. London and New York: Routledge.

Haraway, D.J. (1992) 'The promises of monsters: A regenerative politics for inappropriate/d others'. In L. Grossberg, C. Nelson, P.A. Treichler (eds), Cultural Studies (pp. 295-337). New York: Routledge. 
Haraway, D.J. (1994) 'A game of cat's cradle: Science studies, feminist theory, cultural studies', Configurations, 2(1): 59-71.

Haraway, D.J. (1997) Modest_Witness@Second_Millennium. FemaleMan_Meets_ OncoMouse: Feminism and Technoscience. New York: Routledge.

Hart, K. (2010) 'The book review: Stuff by Daniel Miller', Open Anthropology Cooperative Press: www.openanthcoop.net/press

Hill, T., Canniford, R. and Mol, J. (2014) 'Non-representational marketing theory', Marketing Theory, 14(4): 377-394.

Hirschman, E.C. (1986) 'Humanistic inquiry in marketing research: Philosophy, method, and criteria', Journal of Marketing Research, 23(3): 237-249.

Horst, H.A. and Miller, D. (2013) Digital Anthropology. Edinburgh: A\&C Black.

Hoskins, J. (2006) 'Agency, Biography and Objects'. In C. Tilley et al. (eds), Handbook of Material Culture (pp. 74-84). London: Sage.

Hui, A. (2012) 'Things in motion, things in practices: How mobile practice networks facilitate the travel and use of leisure objects', Journal of Consumer Culture, 12(2): 195-215.

Kopytoff, I. (1986) 'The cultural biography of things: Commoditization as process', in A. Appadurai (ed.), The Social Life of Things: Commodities in Cultural Perspective (pp. 70-73). Cambridge: CUP.

Ladik, D., Carrillat, F. and Tadajewski, M. (2015) 'Belk's (1988) "Possessions and the Extended Self” Revisited', Journal of Historical Research in Marketing, 7(2): 184-207.

Latour, B. (1987) Science in Action: How to Follow Scientists and Engineers Through Society. Cambridge, MA: Harvard University Press 
Latour, B. (1988) The Pasteurisation of France. Cambridge, MA: Harvard University Press.

Latour, B. (1992) ‘Where are the missing masses?’ In W.E. Bijker and J. Law (eds), Shaping Technology/Building Society: Studies in Sociotechnical Change (pp. 225-258). Cambridge, MA: MIT Press.

Latour, B. (2000) 'When things strike back: A possible contribution of "science studies" to the social sciences', The British Journal of Sociology, 51(1): 107-123.

Latour, B. (2005) Reassembling the Social: An Introduction to Actor-Network-Theory. Oxford: OUP.

Law, J. (1992) 'Notes on the theory of the actor-network: Ordering, strategy, and heterogeneity', Systems Practice, 5(4): 379-393.

Law, J. (1999) 'After ANT: Complexity, Naming and Topology', The Sociological Review, 47(S1): 1-14.

Law, J. (2008) 'Actor-network theory and material semiotics'. In B.S. Turner (ed.), The New Blackwell Companion to Social Theory, 3rd Edition (pp. 141-158). Oxford: Blackwell.

Lingis, A. (1998) The Imperative. Bloomington: Indiana University Press.

MacKenzie, D. and Wajcman, J. (1999) The Social Shaping of Technology. Buckingham: Open University Press.

Malinowski, B. (1922/1961) Argonauts of the Western Pacific. New York: Dutton.

Martin, D.M. and Schouten, J.W. (2014) ‘Consumption-driven market emergence', Journal of Consumer Research, 40(5): 855-870.

Mauss, M. (1925/1990) The Gift: Forms and Functions of Exchange in Archaic Societies. New York: Norton. 
Miller, D. (1987) Material Culture and Mass Consumption. Oxford: Blackwell.

Miller, D. (1998) Material Cultures: Why Some Things Matter. Chicago: University of Chicago Press.

Miller, D. (2010) Stuff. Cambridge: Polity Press.

Miller, D. and Tilley, C. (1996) Editorial. Journal of Material Culture, 1(1): 5-14.

Molz, J.G. (2013) 'Social networking technologies and the moral economy of alternative tourism: The case of couchsurfing.org', Annals of Tourism Research, 43: 210-230.

Molz, J.G. and Paris, C.M. (2015) The social affordances of flashpacking: Exploring the mobility nexus of travel and communication. Mobilities, 10(2): 173-192.

Morton, T. (2013) Hyperobjects: Philosophy and ecology after the end of the world. Minneapolis: University of Minnesota Press.

Nowak, R. (2016) Consuming Music in the Digital Age: Technologies, Roles and Everyday Life. London: Palgrave Macmillan.

Parmentier, M.A. and Fischer, E. (2015) 'Things fall apart: The dynamics of brand audience dissipation', Journal of Consumer Research, 41(5): 1228-1251.

Pfaffenberger, B. (1992) ‘Social anthropology of technology', Annual Review of Anthropology, 21(1): 491-516.

Thomas, T.C., Price, L.L. and Schau, H.J. (2013) 'When differences unite: Resource dependence in heterogeneous consumption communities', Journal of Consumer Research, 39(5): 1010-1033. 
Treem, J.W. and Leonardi, P.M. (2013) 'Social media use in organizations: Exploring the affordances of visibility, editability, persistence, and association', Annals of the International Communication Association, 36(1): 143-189.

Wijetunga, D. (2014) 'The digital divide objectified in the design: Use of the mobile telephone by underprivileged youth in Sri Lanka', Journal of Computer-Mediated Communication, 19(3): $712-726$.

Williams-Bradford, T.W. and Sherry, J.F. (2015) 'Domesticating public space through ritual: Tailgating as vestaval', Journal of Consumer Research, 42(1): 130-151.

Withagen, R., de Poel, H.J., Araújo, D. and Pepping, G.J. (2012) 'Affordances can invite behavior: Reconsidering the relationship between affordances and agency', New Ideas in Psychology, 30(2): 250-258.

Wright, S. and Parchoma, G. (2011) 'Technologies for learning? An actor-network theory critique of "affordances" in research on mobile learning', Research in Learning Technology, 19(3): $247-258$. 